\title{
Synthesis and properties of oligo(2,5-thienylene-ethynylene)s
}

\author{
Herbert Meier* and Bastian Mühling \\ Institute of Organic Chemistry, Johannes-Gutenberg University, \\ Mainz, Germany \\ E-mail:.hmeier@mail.uni-mainz.de
}

\begin{abstract}
Oligo(2,5-thienylene-ethynylene)s [OTE] are a class of conjugated oligomers with a high shapepersistence as rigid rods, which give these "molecular wires" interesting properties in materials science. The synthetic approach to OTEs is based on iterative Sonogashira-Hagihara reactions and possible end-cappings with certain functional groups or sub-structures. Special attention is focused on systems with terminal donor-acceptor substitution DAOTEs which exhibit an unusual absorption behavior. Increasing numbers of repeating units lead in OTEs to a convergent bathochromic effect; on the contrary, hypsochromic shifts can be observed for DAOTEs with a strong push-pull effect.
\end{abstract}

Keywords: Absorption, conjugation, oligomers, polymers, push-pull effect, SonogashiraHagihara reaction

\section{Contents}

1. Introduction

2. Synthesis of Oligo(2,5-thienylene-ethynylene)s

3. Absorption and Fluorescence

4. Summary and Outlook

5. References and Notes

\section{Introduction}

Conjugated oligomers and polymers attract increasing attention because of their interesting properties in materials science. ${ }^{1}$ Among the variety of applications, semiconductive, photoconductive, electroluminescent, nonlinear optical, photorefractive and sensor systems play a prominent role. ${ }^{1}$ 
Whereas the number of publications on arylene-ethynylenes $\mathbf{1}$ is legendary, relatively little is known about the hetarylene-ethynylenes $\mathbf{2}$ and $\mathbf{3}$.

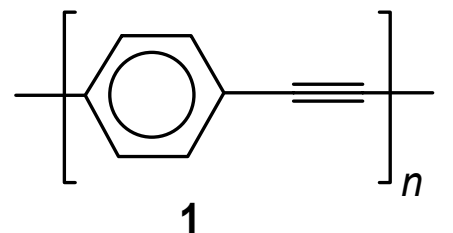

1

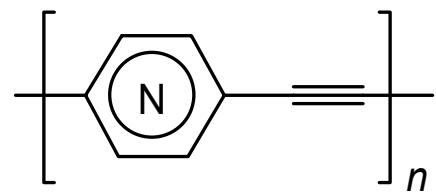

2

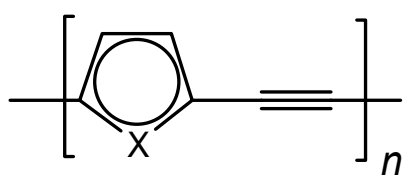

$3(X=N R, O, S)$

\section{Scheme 1}

The oligomers $2(n \geq 2)$ containing pyridine, pyridazine, pyrimidine, triazine and tetrazine rings are, to our best knowledge, unknown. A dimer $(n=2)$ was reported for compounds 2 with pyrazine rings $^{2}$ and a polymer chain $\mathbf{2}$, which contains pyridine rings. ${ }^{3,4}$ In series $\mathbf{3}$, the systems with $\mathrm{X}=\mathrm{NR}$ and $\mathrm{O}(n \geq 2)$ are unknown. Most of the studies have been on oligo(2,5-thienyleneethynylene)s [OTE] 3 (X=S), [which can also be called oligo(2,5-thiophenediyl-1,2ethynediyl)s], and the corresponding polymers [PTE.$^{5-34}$

\section{Synthesis of Oligo(2,5-thienylene-ethynylene)s}

The Sonogashira-Hagihara reaction ${ }^{35}$ represents the method of choice for the preparation of OTEs and PTEs. ${ }^{1 \mathrm{~m}}$ More than $95 \%$ of all known compounds of these types were synthesized with this $\mathrm{Pd}$ - catalyzed coupling reaction, which is superior to other $\mathrm{C}\left(\mathrm{sp}^{2}\right)-\mathrm{C}(\mathrm{sp})$ couplings such as the Stephens-Castro process. ${ }^{36}$ 


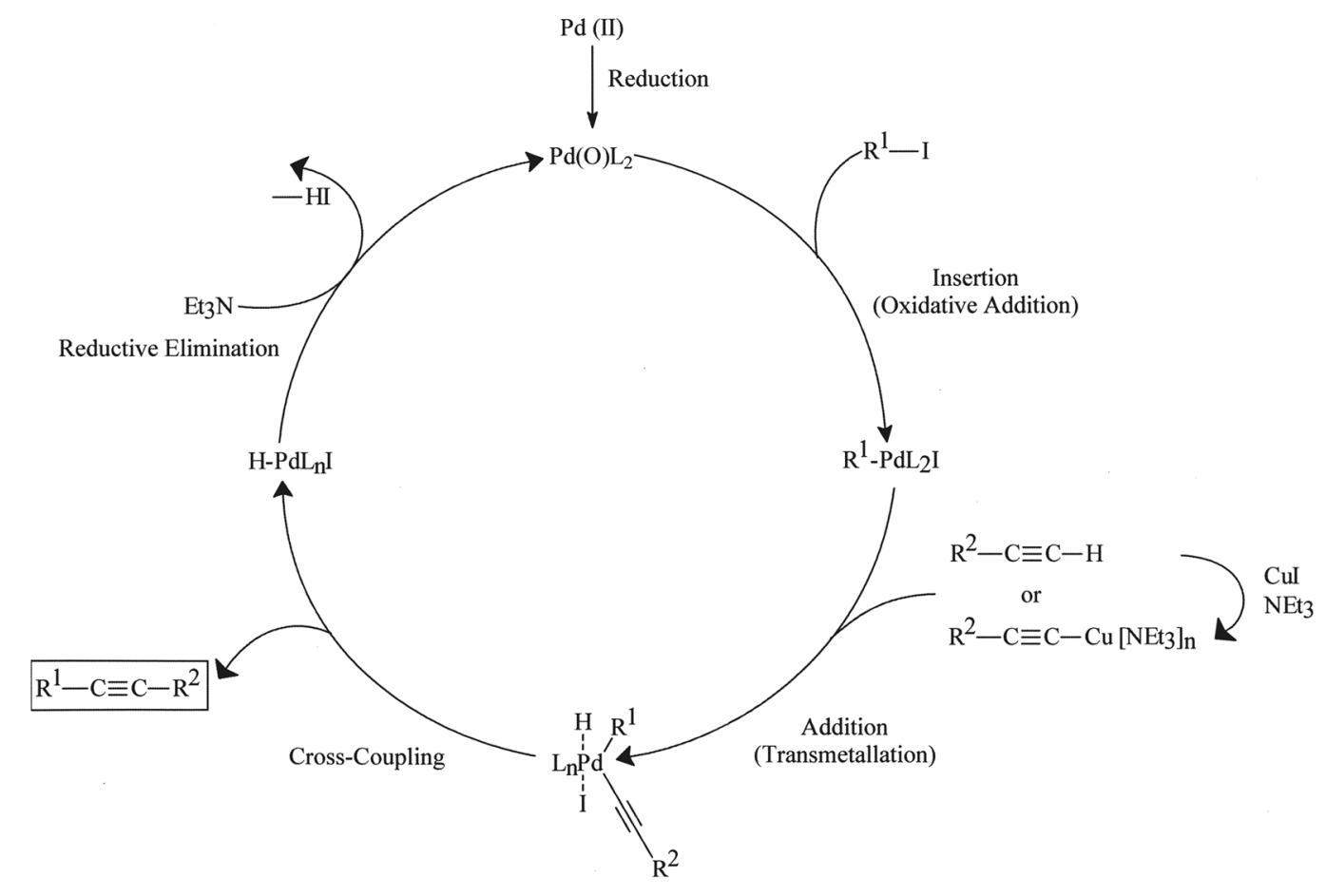

\section{Scheme 2}

Scheme 2 shows the catalytic circle of the Sonogashira-Hagihara reaction. When $\mathrm{Pd}^{2+}$ is used, for example as $\operatorname{Pd}\left(\mathrm{PPh}_{3}\right)_{2} \mathrm{Cl}_{2}$, a primary reduction to $\mathrm{Pd}(0)$ has to take place. Dialkynes, as oxidation products, are then minor by-products. $\mathrm{Pd}(0)$ is inserted into the $\mathrm{C}-\mathrm{Hal}$ bond of $\mathrm{R}^{1}-\mathrm{I}$ or $\mathrm{R}^{1}-\mathrm{Br}\left(\mathrm{R}^{1}=\right.$ thienyl). The co-catalyst $\mathrm{CuI}$ generates from $\mathrm{R}^{2}-\mathrm{C} \equiv \mathrm{CH}\left(\mathrm{R}^{2}=\right.$ thienyl) a copper acetylide, which provokes a transmetallation. The next step in the circle consists of the crosscoupling to yield $\mathrm{R}^{1} \mathrm{C} \equiv \mathrm{CR}^{2}$. Complexed $\mathrm{Pd}(0)$ and $\mathrm{HI}$ (or $\mathrm{HBr}$ ) are formed. The acid is trapped by the present base $\left(\mathrm{Et}_{3} \mathrm{~N}\right)$. Triphenylphosphine serves as ligand $\mathrm{L}$ for the $\mathrm{Pd}$ complexes.

The relatively rigid conjugated OTE chains $3(\mathrm{X}=\mathrm{S})$ soon become $(n \geq 4)$ insoluble unless solubilizing side chains are attached. Therefore, alkyl, ${ }^{11,13,14,18,19,21-23,25-28,31-33}$ aryl, ${ }^{17}$ alkoxy ${ }^{34}$ or alkylsulfanyl $^{34}$ groups are normally attached to one or both free positions of the thiophene rings. Apart from OTEs with (substituted)- thienyl and/or free or protected ethynyl end-groups, some systems with special end-groups have been investigated: benzene, ${ }^{21,31,32}$ fluorene, ${ }^{13}$ fullerene, ${ }^{23}$ aldehyde, ${ }^{23,32}$ ester, ${ }^{21}$ thioester, ${ }^{21} 1,3,4$-oxadiazole, ${ }^{29 a} 2,2^{\prime}: 6^{\prime}, 2^{\prime \prime}$-terpyridine. ${ }^{27,28}$

We were mainly interested in the synthesis of push-pull substituted OTEs, which bear an electron- donor group, D, on one end and an electron- acceptor group, A, on the other end of the conjugated chain. Therefore, we conceived a convergent and coupled synthetic strategy. "Coupled" means that certain donor- substituted OTE chains $\left(\mathrm{D}=\mathrm{OCH}_{3}, \mathrm{SC}_{12} \mathrm{H}_{25}\right)$ can be reacted with different acceptor components $\left(\mathrm{A}=\mathrm{CHO}, \mathrm{NO}_{2}\right)$ in the final end-capping step. Scheme 3 shows this concept. ${ }^{37,38}$ 


\section{Chain extension}<smiles>[2H]C#Cc1ccc([2H])s1</smiles>

4<smiles>[2H]c1ccc(C#Cc2ccc(C#C[SiH2]C)s2)s1</smiles>

6

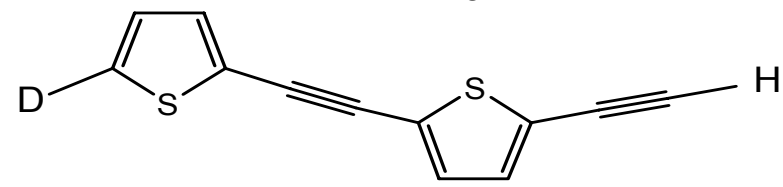

7

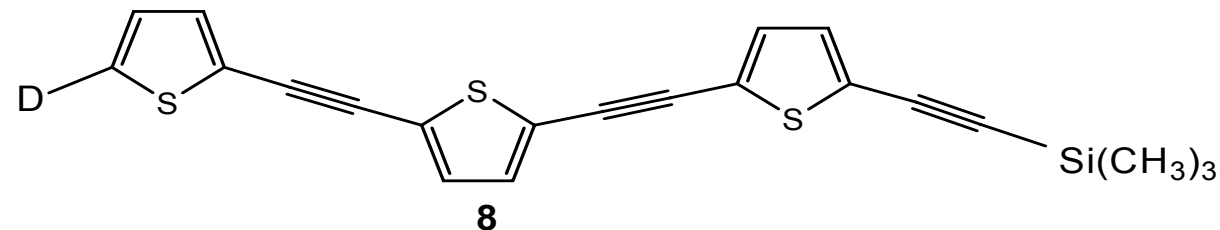

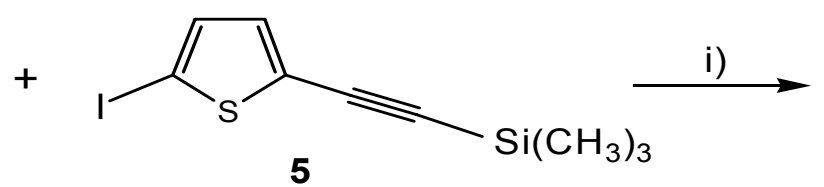

ii)

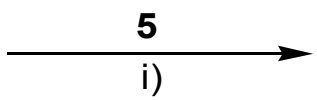

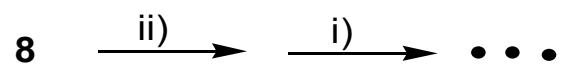

End-capping<smiles>[2H]C(C)(C)C#Cc1ccc(C)s1</smiles>

9

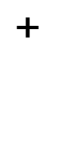<smiles>Ic1ccc(I)s1</smiles>

10<smiles>[2H]C(C)(C)c1ccc(C#CC(C)(C)c2ccc(I)s2)s1</smiles>

D: $\mathrm{OCH}_{3}, \mathrm{SC}_{12} \mathrm{H}_{25}$

A: $\mathrm{CHO}, \mathrm{NO}_{2}$

11

i) $\mathrm{Pd} / \mathrm{Cul}, \mathrm{PPh}_{3}$, base, toluene; ii) $\mathrm{K}_{2} \mathrm{CO}_{3}, \mathrm{CH}_{3} \mathrm{OH} / \mathrm{CH}_{2} \mathrm{Cl}_{2}$

\section{Scheme 3}

The chain- extension consists of an alternating sequence of coupling reactions $(\mathbf{4}+\mathbf{5} \rightarrow \mathbf{6}, \mathbf{7}$ $+5 \rightarrow \mathbf{8}$, etc. ) and deprotection reactions $(\mathbf{6} \rightarrow 7,8 \rightarrow$, etc.). Due to solubility problems, the starting compound is always the donor substituted system $\mathbf{4}$. Compound $\mathbf{5}$ is the chain- extension 
component which increases the number of the repeating units from $n$ to $n+1$, and $\mathbf{1 0}$ or the corresponding bromo- compound is the end-capping component. In the present case, the monodisperse OTEs 12-20 listed in Table 1 were prepared. ${ }^{37-39}$ The compounds with 2,2dicyanovinyl end-groups were obtained from the corresponding aldehydes by condensation reactions with malononitrile. With increasing numbers, $n$, of repeating units the yields of 12$\mathbf{1 6},{ }^{37} \mathbf{1 7},{ }^{39}$ and $\mathbf{1 8}-\mathbf{2 0},{ }^{38}$ decrease. The preparations were stopped at $n=4,5$ because the solubility then becomes very low.

Table 1. Oligo(2,5-thienyleneethynylene)s [OTE]

$$
\begin{aligned}
& \mathrm{D}-\mathrm{C}_{4} \mathrm{H}_{2} \mathrm{~S}-\mathrm{C} \equiv \mathrm{C} \mathrm{f}_{n} \mathrm{Si}\left(\mathrm{CH}_{3}\right)_{3} \quad \mathbf{1 2}, \mathbf{1 8}, \\
& \left.\mathrm{D}-\mathrm{C}_{4} \mathrm{H}_{2} \mathrm{~S}-\mathrm{C} \equiv \mathrm{C}\right\}_{n} \mathrm{H} \quad 13,19, \\
& \mathrm{D}-\mathrm{C}_{4} \mathrm{H}_{2} \mathrm{~S}-\mathrm{C} \equiv \mathrm{C} \mathrm{f}_{n} \mathrm{C}_{4} \mathrm{H}_{2} \mathrm{~S}-\mathrm{H} \quad \mathbf{1 4} \text {, } \\
& \left.\mathrm{D}-\mathrm{C}_{4} \mathrm{H}_{2} \mathrm{~S}-\mathrm{C} \equiv \mathrm{C}\right]_{n} \mathrm{C}_{4} \mathrm{H}_{2} \mathrm{~S}-\mathrm{CHO} \quad \mathbf{1 5} \text {, } \\
& \left.\mathrm{D}-\mathrm{C}_{4} \mathrm{H}_{2} \mathrm{~S}-\mathrm{C} \equiv \mathrm{C}\right\}_{n} \mathrm{C}_{4} \mathrm{H}_{2} \mathrm{~S}-\mathrm{NO}_{2} \quad \mathbf{1 6}, 20 \text { and } \\
& \mathrm{D}-\mathrm{C}_{4} \mathrm{H}_{2} \mathrm{~S}-\mathrm{C} \equiv \mathrm{C} \mathrm{f}_{n} \mathrm{C}_{4} \mathrm{H}_{2} \mathrm{~S}-\mathrm{CH}=\mathrm{C}\left(\mathrm{CN}_{2}\right) \quad 17 .
\end{aligned}
$$

\begin{tabular}{|c|c|c|c|c|c|c|c|c|c|c|}
\hline $\begin{array}{l}\text { End- } \\
\text { groups }\end{array}$ & $\begin{array}{l}\mathrm{D} \\
\text { (A) }\end{array}$ & $\begin{array}{l}\mathrm{OCH}_{3} \\
\mathrm{C} \equiv \mathrm{CSi} \\
\left(\mathrm{CH}_{3}\right)_{3}\end{array}$ & $\begin{array}{l}\mathrm{OCH}_{3} \\
\mathrm{C} \equiv \mathrm{CH}\end{array}$ & $\begin{array}{c}\mathrm{OCH}_{3} \\
\mathrm{H}\end{array}$ & $\begin{array}{l}\mathrm{OCH}_{3} \\
\mathrm{CHO}\end{array}$ & $\begin{array}{c}\mathrm{OCH}_{3} \\
\mathrm{NO}_{2}\end{array}$ & $\begin{array}{l}\mathrm{OCH}_{3} \\
\mathrm{CH}=\mathrm{C} \\
(\mathrm{CN})_{2}\end{array}$ & $\begin{array}{c}\mathrm{SC}_{12} \mathrm{H}_{25} \\
\mathrm{C} \equiv \mathrm{CSi} \\
\left(\mathrm{CH}_{3}\right)_{3}\end{array}$ & $\begin{array}{c}\mathrm{SC}_{12} \mathrm{H}_{25} \\
\mathrm{C} \equiv \mathrm{CH}\end{array}$ & $\begin{array}{c}\mathrm{SC}_{12} \mathrm{H}_{25} \\
\mathrm{NO}_{2}\end{array}$ \\
\hline \multirow[t]{5}{*}{$n=$} & 1 & $\begin{array}{l}12 a \\
(57)\end{array}$ & $\begin{array}{l}13 \mathbf{a} \\
(98)\end{array}$ & $\begin{array}{l}14 a \\
(60)\end{array}$ & $\begin{array}{l}\mathbf{1 5 a} \\
(59)\end{array}$ & $\begin{array}{l}16 \mathbf{a} \\
(76)\end{array}$ & $\begin{array}{l}17 \mathbf{a} \\
(93)\end{array}$ & $\begin{array}{l}\mathbf{1 8 a} \\
(87)\end{array}$ & $\begin{array}{l}19 a \\
(89)\end{array}$ & $\begin{array}{l}\mathbf{2 0 a} \\
(82)\end{array}$ \\
\hline & 2 & $\begin{array}{l}\mathbf{1 2 b} \\
(82)\end{array}$ & $\begin{array}{l}\mathbf{1 3 b} \\
(88)\end{array}$ & $\begin{array}{l}14 b \\
(56)\end{array}$ & $\begin{array}{l}\mathbf{1 5 b} \\
(55)\end{array}$ & $\begin{array}{l}\mathbf{1 6 b} \\
(88)\end{array}$ & $\begin{array}{l}\mathbf{1 7 b} \\
(94)\end{array}$ & $\begin{array}{l}\mathbf{1 8 b} \\
(95)\end{array}$ & $\begin{array}{l}19 b \\
(93)\end{array}$ & $\begin{array}{l}\mathbf{2 0 b} \\
(64)\end{array}$ \\
\hline & 3 & $\begin{array}{l}12 c \\
(88)\end{array}$ & $\begin{array}{l}\mathbf{1 3 c} \\
(99)\end{array}$ & $\begin{array}{l}14 c \\
(52)\end{array}$ & $\begin{array}{l}15 c \\
(57)\end{array}$ & $\begin{array}{l}\mathbf{1 6 c} \\
(83)\end{array}$ & $\begin{array}{l}17 c \\
(89)\end{array}$ & $\begin{array}{l}18 c \\
(47)\end{array}$ & $\begin{array}{l}19 c \\
(89)\end{array}$ & $\begin{array}{l}\mathbf{2 0 c} \\
(48)\end{array}$ \\
\hline & 4 & $\begin{array}{l}\text { 12d } \\
(86)\end{array}$ & $\begin{array}{l}\mathbf{1 3 d} \\
(89)\end{array}$ & $\begin{array}{l}\text { 14d } \\
(41)\end{array}$ & $\begin{array}{l}15 d \\
(49)\end{array}$ & $\begin{array}{l}\text { 16d } \\
(71)\end{array}$ & $\begin{array}{l}17 d \\
(62)\end{array}$ & $\begin{array}{l}\text { 18d } \\
(66)\end{array}$ & $\begin{array}{l}\text { 19d } \\
(93)\end{array}$ & $\begin{array}{l}\text { 20d } \\
(37)\end{array}$ \\
\hline & 5 & $\begin{array}{l}12 \mathrm{e} \\
(68)\end{array}$ & $\begin{array}{l}\mathbf{1 3 e} \\
(82)\end{array}$ & $\begin{array}{l}14 \mathrm{e} \\
(30)\end{array}$ & $\begin{array}{l}\mathbf{1 5 e} \\
(37)\end{array}$ & $\begin{array}{l}16 e \\
(48)\end{array}$ & $\begin{array}{l}17 e \\
(38)\end{array}$ & & & \\
\hline
\end{tabular}

The numbers in parenthesis represent the yields (\%) of the final preparation steps according to Scheme $3: \mathbf{1 2 - 1 6} \mathbf{6}^{37}, \mathbf{1 7}^{39}, \mathbf{1 8 - 2 0 ^ { 3 8 }}$.

When compound 5 of Scheme 3 is deprotected and then subjected to the SonogashiraHagihara reaction conditions, a mixture of oligomers results. ${ }^{40}$ However, the chain lengths are short, unless solubilizing side chains are attached to the thiophene ring. When the same 
procedure was applied to 2-ethynyl-3-hexyl-5-iodothiophene, a polymer was obtained for which $n=56$ and $\mathrm{M}_{\mathrm{w}} / \mathrm{M}_{\mathrm{n}}=1.9$ was reported. ${ }^{18}$ An analogous polycondensation was achieved with 2bromo-4-(3,5-di-tert-butyl-4-hydroxyphenyl)-5-ethynylthiophene. ${ }^{17}$ In addition to these $\mathrm{AB}$ types of polycondensation, AABB cases can be realized. ${ }^{1 \mathrm{~m}}$ Scheme 4 demonstrates such a procedure. Due to the lack of symmetry of the components 21 and 22 (point group $C_{\mathrm{s}}$ ), the obtained polymer $\mathbf{2 3}$ is regio-irregular. ${ }^{15}$ On the contrary, the components $\mathbf{2 4}$ and $\mathbf{2 5}\left(C_{2 \mathrm{~h}}\right.$ or $C_{2 \mathrm{v}}$ symmetry) yield a regio-regular chain $\mathbf{2 6} .^{18}$

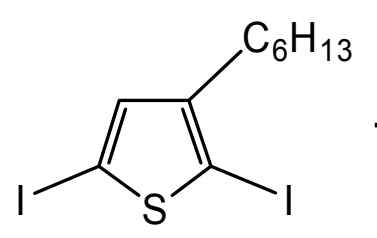

$21(\mathrm{AA})$

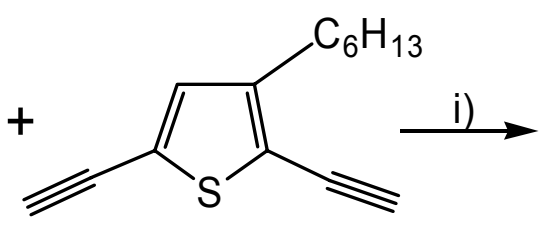

$22(\mathrm{BB})$

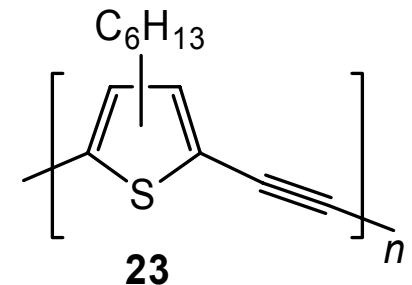

23<smiles></smiles>

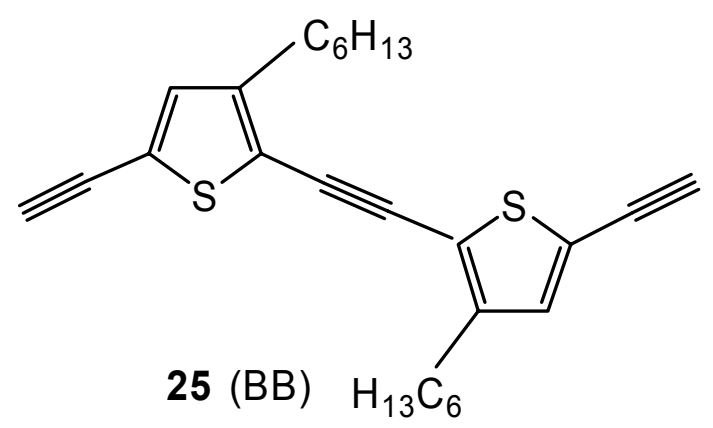

$24+25 \stackrel{\text { i) }}{\longrightarrow}$

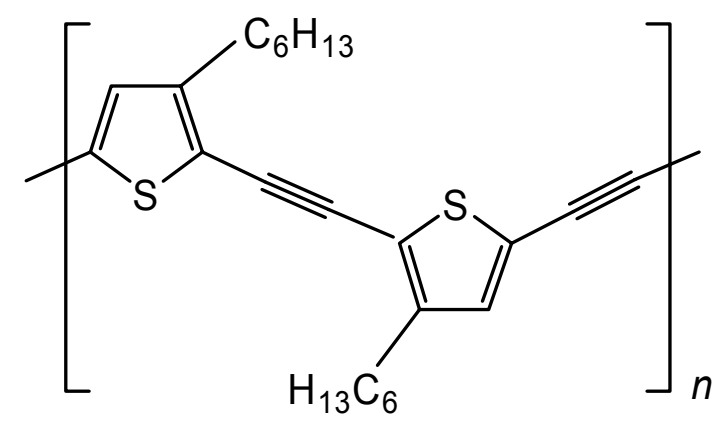

i) SonogashiraHagihara reaction conditions $^{35}$

26

\section{Scheme 4}

At the end of this Section we should mention that connected OTE chains, ${ }^{13}$ branched OTE systems ${ }^{41}$ star-shaped OTE structures, ${ }^{42}$ and even cyclic OTEs have been reported. ${ }^{32}$ 


\section{UV/Vis Absorption and Fluorescence}

Normal (i.e., not push-pull substituted) OTEs show long-wavelength absorption bands, which exhibit a bathochromic- and a hyperchromic- effect with increasing length of the conjugated chains (increasing numbers $n$ of repeating units). Table 2 summarizes the $\lambda_{\max }$ values and the $\log$ $\varepsilon$ values of the OTEs 12, 13 and 14 .

Table 2. UV/Vis absorption maxima of $13 \mathbf{a}-\mathbf{e}, \mathbf{1 2 a}-\mathbf{e}$ and $\mathbf{1 4 a}-\mathbf{e}$ in $\mathrm{CHCl}_{3}$

\begin{tabular}{cccccccccc}
\hline$n$ & $\mathbf{1 3}$ & $\begin{array}{c}\lambda_{\max } \\
/ \mathrm{nm}\end{array}$ & $\log \varepsilon$ & $\mathbf{1 2}$ & $\begin{array}{c}\lambda_{\max } \\
/ \mathrm{nm}\end{array}$ & $\log \varepsilon$ & $\mathbf{1 4}$ & $\begin{array}{c}\lambda_{\max } \\
/ \mathrm{nm}\end{array}$ & $\log \varepsilon$ \\
\hline 1 & $\mathbf{a}$ & 289 & 4.08 & $\mathbf{a}$ & 297 & 4.17 & $\mathbf{a}$ & 329 & 4.43 \\
2 & $\mathbf{b}$ & 352 & 4.35 & $\mathbf{b}$ & 359 & 4.35 & $\mathbf{b}$ & 373 & 4.49 \\
3 & $\mathbf{c}$ & 386 & 4.60 & $\mathbf{c}$ & 389 & 4.54 & $\mathbf{c}$ & 393 & 4.67 \\
4 & $\mathbf{d}$ & 394 & 4.73 & $\mathbf{d}$ & 399 & 4.78 & $\mathbf{d}$ & 405 & 4.82 \\
5 & $\mathbf{e}$ & 407 & 4.75 & $\mathbf{e}$ & 407 & 4.84 & $\mathbf{e}$ & 414 & 4.86 \\
\hline
\end{tabular}

Similar results were found for the series $\mathbf{2 1}^{21}$ and $\mathbf{2 2}^{31}$ shown in Scheme 5. The longest of these "wires" reach — in the energetically favorable zig-zag conformation ${ }^{21}$ — a length of more than $10 \mathrm{~nm}$. Both series exhibit a typical saturation phenomenon. The $\lambda_{\max }$ values of the fluorescence of 22 show a much smaller red-shift with increasing numbers $n$, than does the absorption (measurements in $\mathrm{CH}_{2} \mathrm{Cl}_{2}$ ).
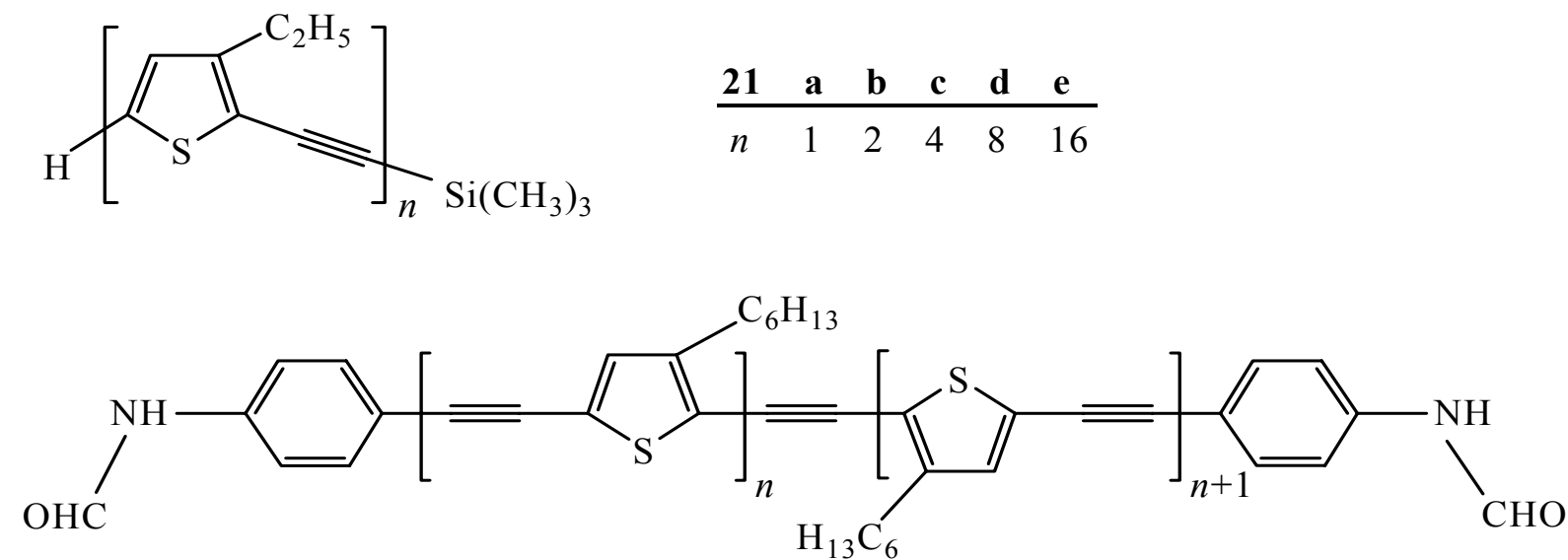

\begin{tabular}{llllll}
$\mathbf{2 2}$ & $\mathbf{a}$ & $\mathbf{b}$ & $\mathbf{c}$ & $\mathbf{d}$ & $\mathbf{e}$ \\
\hline$n$ & 0 & 2 & 4 & 6 & 8
\end{tabular}
A: $\lambda_{\max }[\mathrm{nm}] 364425 \quad 431 \quad 442 \quad 444$
F: $\lambda_{\text {max }}[\mathrm{nm}] 536 \quad 539 \quad 542 \quad 544 \quad 544$

\section{Scheme 5}


Some time ago we suggested an empirical algorithm (equations 1 and 2) based on exponential functions, which allows the determination of the limiting values $\lambda_{\infty}$ of absorption and fluorescence for increasing numbers of repeating units $(n \rightarrow \infty) .{ }^{1 \mathrm{u}, 43}$ The parameters $a$ and $b$, respectively, have to be optimized on the basis of the measured $\lambda_{\max }(n)$. Normally, four data points are sufficient for an accurate prediction of $\lambda_{\infty}$.

According to first- and second- order perturbation theory, the convergence of $\lambda(n)$ is due to different bond lengths (different resonance integrals) in the conjugated chain. Torsions along the chain accelerate the convergence. Hyperbolic approximations for $\lambda_{\infty}$ with $\lambda_{\max }$ as function of $n^{-1}$ with $n^{-1} \rightarrow 0$ furnish too high $\lambda_{\infty}$ values. ${ }^{1 \mathrm{u}, 43,44}$

$$
\begin{aligned}
& E(n)=E_{\infty}+\left(E_{1}-E_{\infty}\right) \mathrm{e}^{-\mathrm{a}(n-1)} \\
& \lambda(n)=\lambda_{\infty}-\left(\lambda_{\infty}-\lambda_{1}\right) \mathrm{e}^{-\mathrm{b}(n-1)} \\
& n_{\mathrm{ECL}}=\ln \left(\lambda_{\infty}-\lambda_{1}\right) \mathrm{b}^{-1}+1
\end{aligned}
$$

The term $\Delta E=\left(E_{1}-E_{\infty}\right)$ gives an answer to the question of, "how much is an absorption or a fluorescence shifted, when going from the very first number $(n=1)$ of the oligomer series to the infinitely long chain". The effective conjugation length, $n_{\mathrm{ECL}}$ (equation 3 ), gives an answer to the question how long a defect-free part of a conjugated polymer chain has to be, in order to match the maximum red-shifted absorption or fluorescence.

Figure 1 illustrates the saturation phenomenon for an oligo-(2,5-thienylene-vinylene) series 23. ${ }^{45,46}$ For comparison, the weak push-pull series $\mathbf{2 0}$ is shown as well. The latter series has a much smaller $\Delta E$ of $0.11 \mathrm{eV}$ compared to $1.38 \mathrm{eV}$ of $\mathbf{2 3}$, and a much lower effective conjugation length $n_{\mathrm{ECL}}=4$ compared to $n_{\mathrm{ECL}}=15$ for 23 .

DAOTEs, as well as other donor-acceptor substituted oligomer series, obviously exhibit a different behavior. ${ }^{1 \mathrm{u}}$ Figure 2 reveals that the normal bathochromic effect of conjugated oligomers for increasing numbers $n$ is reversed when a strong push-pull effect is present. Such a hypsochromic effect for increasing size of the chromophore is unexpected and needs an explanation.

Figure 3 shows a schematic diagram for the long-wavelength electron transition. The HOMO-LUMO energy difference $\Delta E_{0}$ corresponds, according to Koopman's theorem, to the difference of ionization potential, $I P$, and electron affinity, EA. When the HOMO and LUMO are represented by one-electron functions, the energy for the electron correlation $E C$ has additionally to be considered for the energy gap between the first excited singlet state $S_{1}$ and the ground-state $\mathrm{S}_{0}$. The term $E C$ can be expressed by the Coulomb repulsion integral $J$ and the exchange integral $2 K$ (Figure 3). 

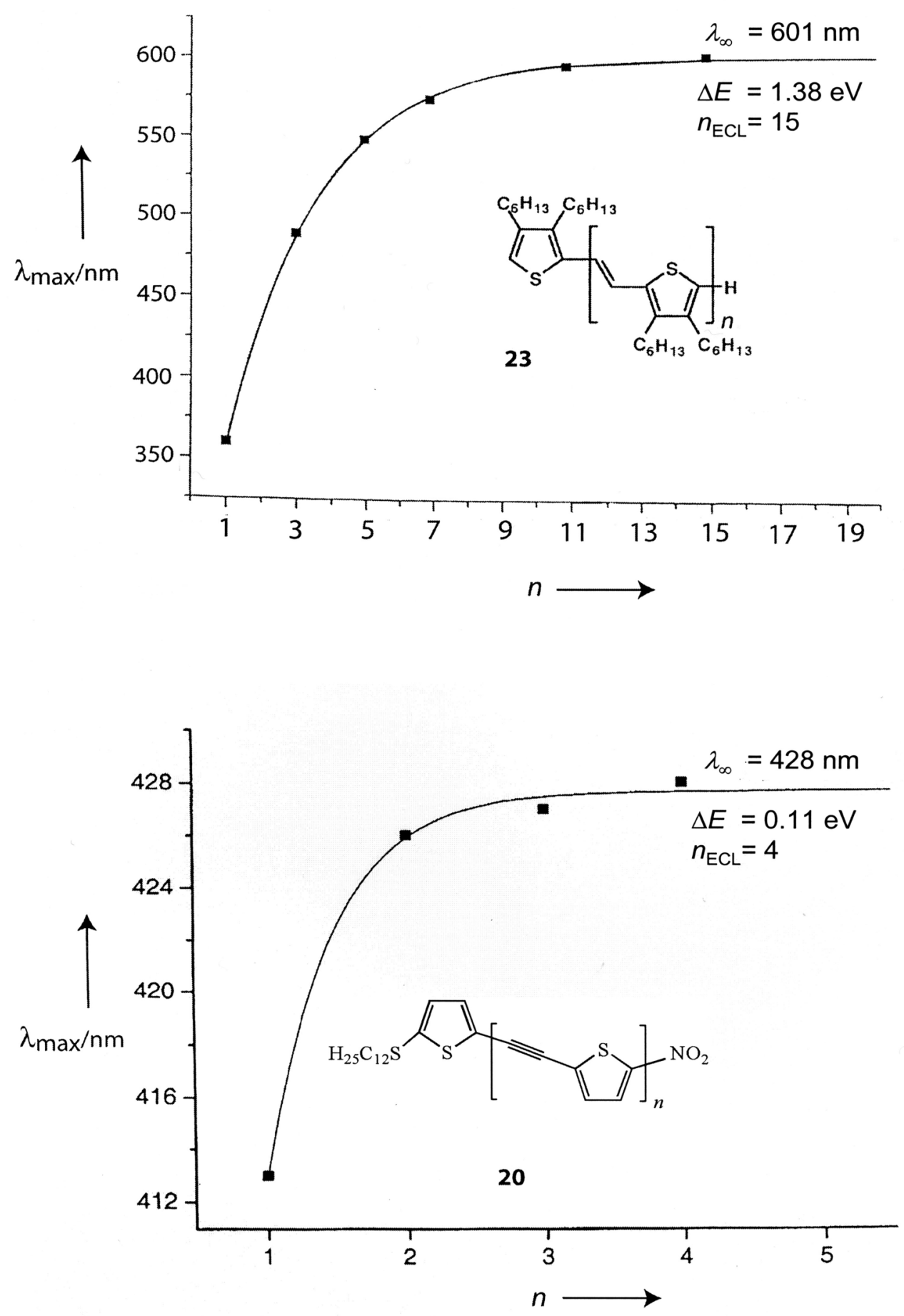

Figure 1. Convergence of the $\lambda_{\max }$ values of the absorption of $23\left(\mathrm{CH}_{2} \mathrm{Cl}_{2}\right)$ and $20\left(\mathrm{CHCl}_{3}\right)$ with increasing numbers $n$. 


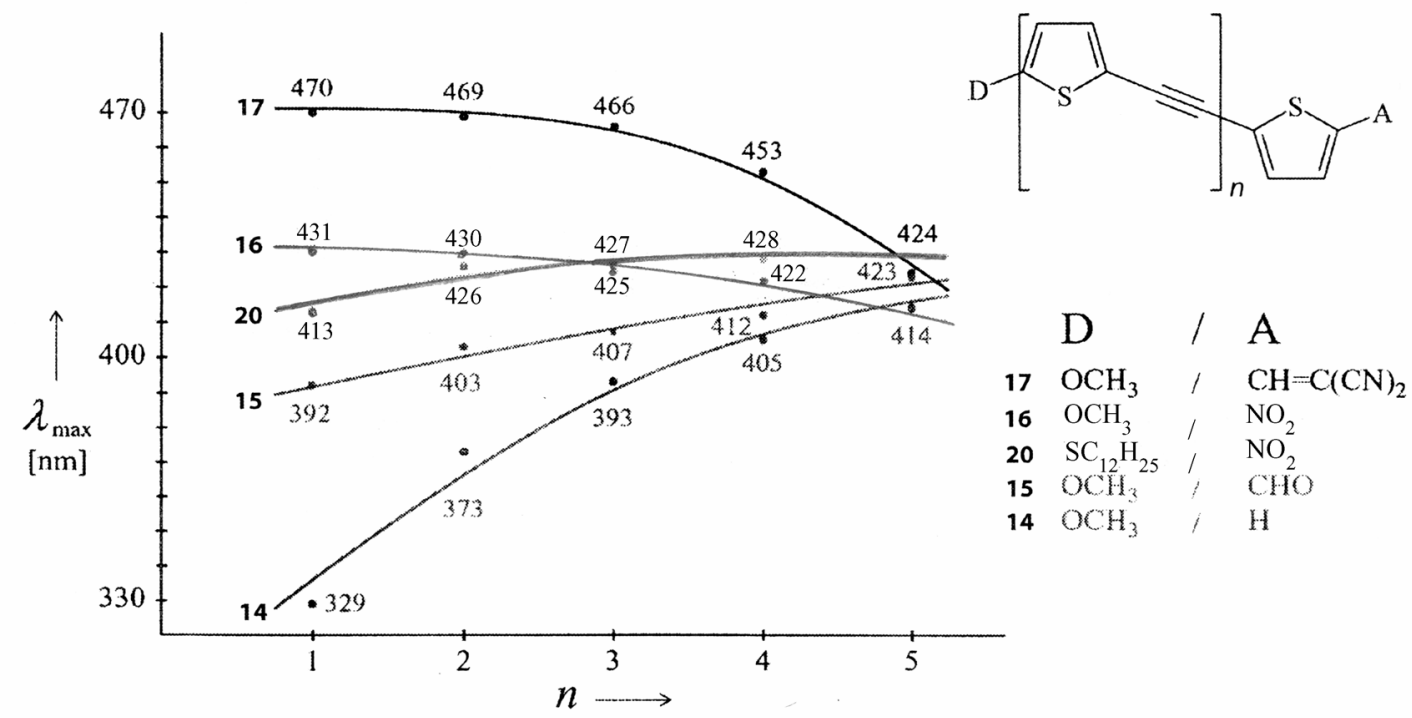

Figure 2. Absorption maxima of the oligomer series 14, 15, 16, 17 and 20 in $\mathrm{CHCl}_{3}$.
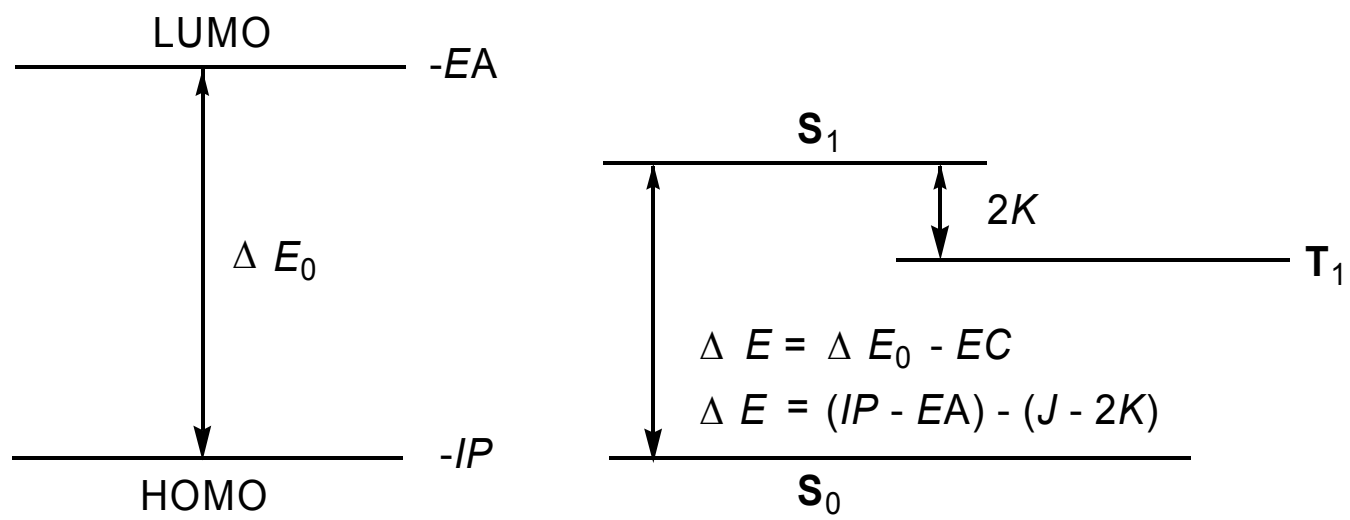

Figure 3. Schematic diagram for the energy of the long-wavelength electron transitions $\mathrm{S}_{0} \rightleftarrows \mathrm{S}_{1}$ (absorption and fluorescence).

The terminal donor-acceptor substitution of a conjugated chain $\mathrm{D}-\pi-\mathrm{A}$, as well as the extension of the chain (higher numbers of repeating units $n$ ), reduce the value of $\Delta E_{0}$, which causes a bathochromic shift. The $\mathrm{S}_{0} \rightarrow \mathrm{S}_{1}$ transition (charge transfer band) is connected to an intramolecular charge transfer ICT, which lowers the electron density on the donor side and increases it on the acceptor side. Consequently the repulsion integral $J$ is decreased. Due to the negative sign of $J$ in the equation for $\Delta E$ (Figure 3), decreasing $J$-values lead to a hypsochromic effect. Since the exchange integral $2 K$ has a minor impact $(J>2 K)$, the crucial question is, which of the two opposite effects prevails. The general answer, is that an overall hypsochromic effect is only possible when donor groups and acceptor groups of high strength are present. This is the case in the series $\mathbf{1 6}$ and 17. Moreover, quantum mechanical calculations reveal that beside the HOMO and LUMO other bonding $\pi$ orbitals and antibonding $\pi^{*}$ orbitals have to be considered for the $\mathrm{S}_{0} \rightarrow \mathrm{S}_{1}$ transitions. ${ }^{1 \mathrm{u}}$ The longer the conjugated chains are, the more important is the 
participation of these "next" orbitals, who normally diminish the ICT. The charge-transfer band then loses more and more its charge-transfer character with increasing numbers, $n$, of repeating units. The interference of other orbitals explains also the increasing absorption intensity with increasing chain length. A strong ICT over a wide distance for the HOMO $\rightarrow$ LUMO transition would otherwise cause a decreasing overlap density and therefore a decreasing band intensity.

\section{Summary and Outlook}

Alternating application of Sonogashira-Hagihara reactions and deprotection reactions provides an effective and reliable strategy for the preparation of uniform oligo-(2,5-thienyleneethynylene)s [OTE]. The largest monodisperse OTEs have a length of more than $10 \mathrm{~nm}$. The corresponding Pd- catalyzed polycondensations of AB- or AABB- type serve for the formation of PTEs, provided that solubilizing pendants are attached to the thiophene rings. Although rotations about the $\mathrm{C}(\mathrm{sp})-\mathrm{C}\left(\mathrm{sp}^{2}\right)$ bonds in OTEs and PTEs can occur, the compounds have a distinct $\pi$ - conjugation, which is expressed in a large bathochromic shift of the long-wavelength absorption maxima $\lambda_{\max }$ for increasing numbers $n$ of repeating units. The convergence limit $\lambda_{\infty}$ lies in solution between 375 and $460 \mathrm{~nm}$. Push-pull substituted systems [DAOTE] show an intramolecular charge transfer (ICT) in the electron excitation $\mathrm{S}_{0} \rightarrow \mathrm{S}_{1}$. The ICT, and the red-shift caused by it, decrease by increasing the numbers of repeating units. The overall effect of $\lambda_{\max }$ can be bathochromic $\left[\lambda_{\max }(n+1)>\lambda_{\max }(n)\right]$ or hypsochromic $\left[\lambda_{\max }(n+1)<\lambda_{\max }(n)\right]$. The latter case is realized in DAOTEs which have a strong push-pull effect. Such molecules with an extended conjugation have a high polarization and yet a high transparency in the visible region. This property predestines them for applications in non-linear optical (NLO) devices. First studies ${ }^{40,47}$ reveal that such oligomer series have a maximum first hyperpolarizability, $\beta$, for a certain chain length $\left(n^{\prime}\right)$ and a steadily increasing second hyperpolarizability $\gamma(n)$. Further interesting applications of OTEs and PTEs can be expected in sensor techniques, as molecular wires in nanotechnology, in light-emitting diodes (LED), and field- effect transistors (FET).

\section{References and Notes}

1. Selected books and review articles: (a) Salaneck, W. R.; Lundström, I.; Ranby, B. R. Conjugated Polymers and Related Materials; Oxford University Press: Oxford, U.K., 1993.

(b) Tour, J. M. Chem. Rev. 1996, 96, 537. (c) Moore, J. S. Acc. Chem. Res. 1997, 30, 402413. (d) Roncali, J. Chem. Rev. 1997, 97, 173. (e) Kraft, A.; Grimsdale, A. C.; Holmes, A. B. Angew. Chem. 1998, 110, 416; Angew. Chem. Int. Ed. 1998, 37, 403. (f) Electronic Materials: The Oligomer Approach; Müllen, K., Wegner, G., Eds.; Wiley-VCH: Weinheim, Germany, 1998. (g) Swager, T. M. Acc. Chem. Res. 1998, 31, 201. (h) Diederich, F.; Gobbi, L. Top. Curr. Chem. 1999, 201, 43. (i) Schwab, P. F. H.; Levin, M. D.; Michl, J. Chem. Rev. 
1999, 99,1863. (j) Scherf, U. Top. Curr. Chem. 1999, 201, 163. (k) Martin, R. E.; Diederich, F. Angew. Chem. 1999, 111, 1440; Angew. Chem., Int. Ed. Engl. 1999, 38, 1350. (1) Bunz, U. H. F. Top. Curr. Chem. 1999, 201, 131. (m) Bunz, U. H. F. Chem. Rev. 2000, 100, 1605. (n) Segura, J. L.; Martin, N. J. Mater. Chem. 2000, 10, 2403. (o) Hadziioannou, G.; van Hutten, P. F. Semi-conductivity Polymers; Wiley-VCH: Weinheim, Germany, 2000. (p) Roncali, J. Acc. Chem. Res. 2000, 33, 147. (q) Tour, J. M. Acc. Chem. Res. 2000, 33, 791. (r) Mishra, A.; Behera, R. K.; Behera, P. K.; Mishra, B. K.; Behera, G. B. Chem. Rev. 2000, 100, 1973. (s) Bunz, U. H. F. Acc. Chem. Res. 2001, 34, 998. (t) Szafert, S.; Gladysz, J. A. Chem. Rev. 2003, 103, 4175. (u) Meier, H. Angew. Chem. 2005, 117, 2536; Angew. Chem. Int. Ed. 2005, 44, 2482. (v) Meier, H. in: Carbon-Rich Compounds, Haley, M. M.; Tykwinski, R. R. Eds.; Wiley-VCH: Weinheim, Germany, 2006, 476. (w) Müllen, K.; Scherf, U. Organic Light-Emitting Devices, Wiley-VCH, Weinheim, Germany, 2006.

2. Pieterse, K.; Lauritsen, A.; Schenning, A. P. H. J.; Vekemans, J. A. J. M.; Meijer, E. W. Chem. Eur. J. 2003, 9, 5597.

3. Yamamoto, R.; Takagi, M. (Tatsuta Densen K. K., Japan), Jpn. Kokai Tokyo Koho 1994, JP 06,166,743; Chem. Abstr. 1995, 122, 106787q.

4. Engel, T. M.; Olesik, S. V.; Callstrom, M. R.; Diener, M. Anal. Chem. 1993, 65, 3691.

5. Carpita, A.; Lessi, A.; Rossi, R. Synthesis 1984, 571.

6. Rossi, R.; Carpita, A.; Lezzi, A. Tetrahedron 1984, 40, 2773.

7. D`Auria, M.; Mico, A.; D`Onofrio, F.; Piancatelli, G. Gazz. Chim. Ital. 1989, 119, 201.

8. Chimenti, F.; D`ilario, L.; Ettore, A.; Muraglia, E.; Ortaggi, G.; Sleiter, G. J. Mater. Sci. Lett. 1992, 11, 1532.

9. Tormos, G. V.; Nugara, P. N.; Lakshmikantham, M. V.; Cava, M. P. Synth. Met. 1993, 53, 271.

10. Geisler, T.; Petersen, J. C.; Bjoernholm, T.; Fischer, E.; Larsen, J.; Dehn, C.; Brédas, J.-L.; Tormos, G. V.; Nugara, P. N.; Cava, M. P.; Metzger, R. M. J. Phys. Chem. 1994, 98, 10102.

11. Pearson, D. L.; Schumm, J. S.; Tour, J. M. Macromolecules 1994, 27, 2348.

12. Yamamoto, T.; Yamada, W.; Takagi, M.; Kizu, K.; Maruyama, T.; Orba, N.; Tomaru, S.; Kurihara, T.; Kaino, T.; Kubota, K. Macromolecules 1994, 27, 6620.

13. Wu, R.; Schumm, J. S.; Pearson, D. L.; Tour, J. M. J. Org. Chem. 1996, 61, 6906.

14. Samuel, I. D. W.; Ledoux, I.; Delporte, C.; Pearson, D. L.; Tour, J. M. Chem. Mater. 1996, $8,819$.

15. Pang, Y.; Wang, Z. C.; Barton, T. J. Polym. Prepr. 1996, 37, 333.

16. Yamamoto, T.; Shimizu, T. J. Mater. Chem. 1997, 7, 1967.

17. Hayashi, H.; Yamamoto, T. Macromolecules 1997, 30, 330.

18. Li, J.; Pang, Y. Macromolecules 1997, 30, 7487.

19. Li, J.; Pang, Y. Polym. Prepr. 1997, 38, 213.

20. Zimmer, H.; Sudsuansri, K.; Maik, H. B.; Ziegler, B. Phosphorus, Sulfur, Silicon Rel. Elem. 1997, 122, 269.

21. Pearson, D. L.; Tour, J. M. J. Org. Chem. 1997, 62, 1376. 
22. Pearson, D. L.; Jones II, L.; Schumm, J. S.; Tour, J. M. Synth. Met. 1997, 84, 303.

23. Obara, Y.; Takimiya, K.; Aso, Y.; Otsubo, T. Tetrahedron Lett. 2001, 42, 6877.

24. Polzonetti, G.; Carravetta, V.; Ferri, A.; Altamura, P.; Alagia, M.; Richter, R.; Russo, M. V. Chem. Phys. Lett. 2001, 340, 449.

25. Li, J.; Liao, L.; Pang, Y. Tetrahedron Lett. 2002, 43, 391.

26. Fujitsuka, M.; Makinoshima, T.; Ito, O.; Obara, Y.; Aso, Y.; Otsubo, T. J. Phys. Chem. B 2003, 107, 739 .

27. De Nicola, A.; Ringenbach, C.; Ziessel, R. Tetrahedron Lett. 2003, 44, 183.

28. Ringenbach, C.; De Nicola, A.; Ziessel, R. J. Org. Chem. 2003, 68, 4708.

29. (a) Hughes, G.; Kreher, D.; Wang, C.; Batsanov, A. S.; Bryce, M. R. Org. Biomol. Chem. 2004, 2, 3363. (b) Wang, J.-L.; Luo, J.; Liu, L.-H.; Zhou, Q.-F.; Ma, Y.; Pei, J. Org. Lett. 2006, 8, 2281.

30. Pei, J.; Zhang, W.-Y.; Mao, J.; Zhou, X.-H. Tetrahedron Lett. 2006, 47, 1551.

31. Tam, I. W.; Yan, J.; Breslow, R. Org. Lett. 2006, 8, 183.

32. Nakao, K.; Nishimura, M.; Tamachi, T.; Kuwatani, Y.; Miyasaka, H.; Nishinaga, T.; Iyoda, M. J. Am. Chem. Soc. 2006, 128, 16740.

33. Bednarz, M.; Reineker, P.; Mena-Osteritz, E.; Bäuerle, P. Chem. Phys. 2007, 342, 191.

34. Matthews, J. R.; Goldoni, F.; Kooijman, H.; Spek, A. L.; Schenning, A. P. H. J.; Meijer, E. W. Macromol. Rap. Commun. 2007, 28, 1809.

35. (a)Sonogashira, K.; Tohda, Y.; Hagihara, N. Tetrahedron Lett. 1975, 16, 4467-4470. (b) See also Takahashi, S.; Kuroyama, Y.; Sonogashira, K.; Hagihara, N. Synthesis 1980, 627.

36. Stephens, R. D.; Castro, C. E. J. Org. Chem. 1963, $28,3313$.

37. Meier, H.; Mühling, B.; Oehlhof, A.; Theisinger, S.; Kirsten, E. Eur. J. Org. Chem. 2006, 405.

38. Mühling, B.; Theisinger, S.; Meier, H. Synthesis 2006, 1009.

39. Meier, H.; Mühling, B.; Gerold, J.; Jacob, D.; Oehlhof, A. Eur. J. Org. Chem. 2007, 625.

40. Meier, H. unpublished results.

41. Tanifuji, N.; Irie, M.; Matsuda, K. J. Am. Chem. Soc. 2005, 127, 13344.

42. Pappenfus, T. M.; Mann, K. R. Org. Lett. 2002, 4, 3043.

43. Meier, H.; Stalmach, U.; Kolshorn, H. Acta Polym. 1997, 48, 379.

44. Gierschner, J.; Cornil, J.; Egelhaaf, H.-J. Adv. Mater. 2007, 19, 173.

45. Jestin, I.; Frère, P.; Blanchard, P.; Roncali, J. Angew. Chem. 1998, 110, 990; Angew. Chem. Int. Ed. 1998, 37, 942.

46. Jestin, I.; Frère, P.; Mercier, M.; Levillain, E.; Stievenard, D.; Roncali, J. J. Am. Chem. Soc. 1998, 120, 8150.

47. Koynov, K.; Bahtiar, A.; Bubeck, C.; Mühling, B.; Meier, H. J. Phys. Chem. B 2005, 109, 10184. 